Undas Vol 12. , Nomor 1, Juni 2016 : 39--66

\title{
ANALISIS PENGGUNAAN KOHESI REFERENSI PADA NASKAH DRAMA SISWA SMAN 2 KANDANGAN
}

\author{
Analysis Using Reference Cohesion on a Drama Scripts Used by SMAN 2 Kandangan Students
}

\author{
Indrawati \\ Balai Bahasa Kalimantan Selatan \\ Jalan Jenderal Ahmad Yani Km 32,2, Loktabat, Banjarbaru 70712 Kalimantan Selatan \\ Telepon (0511) 4772641, Pos-el: indra_bhs73@yahoo.co.id
}

\begin{abstract}
Abstrak: Penelitian Analisis Penggunaan Kohesi Referensi pada Naskah Drama Siswa SMAN 2 Kandangan merupakan penelitian deskriptif. Tujuan penelitian ini adalah mendeskripsikan penggunaan kohesi referensi pada naskah drama siswa SMAN 2 Kandangan. Jenis penelitian ini merupakan penelitian deskriptif kualitatif. Populasi data dalam penelitian ini adalah siswa SMAN 2 Kandangan. Objek siswa SMAN 2 Kandangan yang dipilih adalah siswa jurusan IPA dan IPS kelas XI. Teknik penentuan subjek didasarkan pada pengambilan sampel yang dilakukan secara random sampling. Adapun objek penelitian ini adalah penggunaan peranti kohesi referensi dalam naskah drama siswa SMAN 2 Kandangan. Data diperoleh dengan metode membaca dan teknik mencatat. Metode analisisnya menggunakan metode analisi deskriptif kualitatif. Hasil penelitian ini dapat dideskripsikan penggunaan peranti kohesi referensi pada naskah drama siswa SMAN 2 Kandangan, yaitu (1) kohesi referensi pronomina persona adalah pronomina yang dipakai untuk mengacu pada orang. Pronomina persona terdiri atas persona orang pertama tunggal dan jamak, pronomina orang kedu tunggal dan jamak, dan pronomina orang ketiga tunggal dan jamak; (2) kohesi pronomina demonstratif adalah pronomina penunjuk umum, pronomina penunjuk tempat, dan pronomina penunjuk hal ikhwal; (3) kohesi referensi komparatif adalah kohesi referensi yang menyatakan perbandingan unsur yang satu dibandingkan dengan unsur yang lain. Kohesi referensi komparatif terdiri atas kohesi referensi komparatif yang menyatakan kurang, kohesi referensi komparatif yang menyatakan sama, dan kohesi referensi komparatif yang menyatakan lebih.
\end{abstract}

Kata kunci: Kohesi, referensi, naskah drama

Abstract: This study Analisis Penggunaan Kohesi Referensi pada Naskah Drama Siswa SMAN 2 Kandangan is descriptive study. The aim of this study is to describe the using of reference cohesion in drama script by SMAN 2 Kandangan student. This is descriptive qualitative study. The data population is the student of SMAN 2 Kandangan. The object of this study is SMAN 2 Kandangan from Science and Social class of second grade. Subject determination technique is based on random sampling. The data are gained through reading and writing. This study used descriptive qualitative method. The object of this study is the using of reference cohesion instrument in drama script of SMAN 2 Kandangan' students. The result shows that the using of reference cohesion instrument in drama script by the student of SMAN 2 Kandangan are (1) pronomen reference cohesion is pronomen refers to a person. Person pronomen consist of singular and plural of first person. Pronomen singular and plural of second person, and pronomen singular and plural of third person; (2) demonstrative pronomen cohesion is general instruction pronomen, place instruction pronomen, cause instruction pronomen, occurances instruction pronomen; (3) comparative reference cohesion is reference cohesion that stating comparation of one component to the other one. Comparative reference cohesion consists of comparative reference cohesion 
that stating inefficient, comparative reference cohesion that stating equality, and comparative reference cohesion that stating more.

Key words: Kohesion, reference, drama script

\section{PENDAHULUAN}

Menulis adalah salah satu keterampilan berbahasa bukan merupakan keterampilan yang diwariskan secara turun-temurun. Banyak pihak, mengakui bahwa menulis merupakan beban, bahkan menjadi momok yang ditakuti dan menakuti banyak orang. Pada dasarnya, semua orang memiliki potensi untuk dapat menulis. Menyusun suatu gagasan menjadi rangkaian bahasa tulis yang teratur, sistematis, dan logis bukanlah merupakan hal yang mudah, melainkan pekerjaan yang memerlukan latihan terus-menerus dan berkesinambungan. Hal-hal yang dikemukakan dalam tulisan dapat bersumber dari pengalaman pribadi, pengalaman orang lain, atau dari membaca buku. Menulis sebagaimana berbicara, merupakan keterampilan berbahasa yang produktif dan ekspresif. Perbedaannya kegiatan menulis merupakan suatu keterampilan berbahasa yang dapat dipergunakan untuk berkomunikasi secara tidak langsung, tidak secara tatap muka dengan orang lain (tidak langsung), sedangkan berbicara merupakan komunikasi tatap muka (langsung) (Tarigan, 2000:2-3). Senada dengan hal tersebut, Mulyati (2002:2-4) menyatakan bahwa menulis pada hakikatnya menyampaikan ide atau gagasan dan pesan dengan menggunakan lambang grafis (tulisan) kepada orang lain. Oleh karena itu, menulis tidak hanya sekedar menuliskan apa yang ingin diucapkan, tetapi menulis merupakan kegiatan yang terorganisir sedemikian rupa sehingga akan terjadi komunikasi antara penulis dengan pembacanya. Reinking, dkk. (1998:3) menyatakan bahwa menulis itu memiliki beberapa keuntungan, baik untuk penulis maupun pembaca, (1) memberi kesempatan kepada penulis untuk merefleksikan dan meneliti ide yang ingin mereka sampaikan, memberbaharui materi-materi tulisan, (2) menulis menjadikan komunikasi lebih efektif, (3) menulis menjadikan gagasan yang disampaikan dapat dibaca sepanjang masa, dan (4) informasi yang didapat dari tulisan lebih tepat daripada mendengar. Syafi'ie (1988:45) berpendapat bahwa menulis pada dasarnya adalah kegiatan menuangkan gagasan, pendapat, perasaan, keinginan, kemauan, dan informasi ke dalam tulisan kemudian 'mengirimkannya' kepada orang lain. Oleh karena itu, menulis merupakan suatu kegiatan yang produktif dan ekspresif. Menulis membuat seseorang mudah menyampaikan gagasannya tanpa harus bertatap muka dengan pembacanya sehingga menulis menjadi sarana komunikasi yang sangat berguna bagi penulis dan pembacanya. Melalui tulisan seseorang dapat berkreativitas sesuai dengan keinginannya untuk mengemukakan pemikiran dan gagasannya. Jika mengasah potensi dengan baik, tidak menutup 
kemungkinan kita akan menjadi penulis yang tangguh dan andal. Untuk memperoleh hasil yang baik, kegiatan menulis seseorang perlu dipantau secara maksimal agar dapat meminimalisir kesalahan-kesalahannya. Misalnya, kegiatan tulis-menulis yang dilakukan siswa di sekolah. Oleh karena itu, materi kegiatan menulis di sekolah hendaknya mendapat perhatian khusus. Keahlian mengungkapkan pikiran melalui tulisan bukanlah bakat alam yang dibawa setiap orang sejak lahir, melainkan sebuah keterampilan yang dapat dikembangkan melalui proses pembelajaran.

Salah satu proses pembelajaran menulis siswa di SMAN 2 Kandangan adalah mengarang dalam bentuk menulis naskah drama. Melalui naskah drama siswa dapat belajar mengomunikasikan ide dan gagasannya. Dalam menulis naskah drama ini siswa juga dapat belajar merangkaikan kata demi kata menjadi sebuah kalimat tuturan. Di dalam karangan yang berbentuk naskah drama tersebut banyak sekali penggunaan kohesi referensi.

Berdasarkan uraian pada latar belakang di atas, peneliti tertarik untuk melakukan penelitian yang bertujuan untuk mengetahui sejauh mana kemampuan penggunaan kohesi referensi siswa SMAN 2 Kandangan di dalam naskah drama dan mendeskripsikan kohesi referensi apa saja yang digunakan siswa SMAN 2 Kandangan di dalam naskah drama. Lokasi penelitian adalah SMAN 2 Kandangan, Kabupaten Hulu Sungai Selatan, khususnya siswa kelas XI IPA dan kelas XI IPS. Dengan penelitian ini, akan diketahui kemampuan siswa SMAN 2 Kandangan di dalam menggunakan peranti kohesi referensi pada naskah drama.

\section{KERANGKA TEORI}

Kohesi adalah hubungan antarkalimat di dalam wacana baik dalam tataran gramatikal maupun dalam tataran leksikal. Suladi (2000:13) mengatakan bahwa kohesi adalah keserasian hubungan antara unsur yang satu dan unsur yang lain dalam wacana sehingga tercipta pengertian yang apik atau koheren, sedangkan koherensi merupakan pertalian semantik antara unsur yang satu dan unsur yang lainnya dalam wacana. Menurut Halliday dan Hasan (dalam Suladi, 2000:14) menyebut kohesi sebagai suatu satuan semantik yang direalisasikan ke dalam tiga strata sistem bahasa, yaitu: 1) makna (meaning) sebagai sistem, 2) bentuk (wording) sebagai leksikogramatikal, dan 3) bunyi dan tulisan (sounding/writing) sebagai sistem fonoilogis dan morfologis. Jadi, dapat diartikan bahwa kohesi suatu wacana yang berupa pertalian unit semantik yang diwujudkan menjadi bentuk gramatikal dan leksikal, selanjutnya diwujudkan dalam bentuk bunyi dan tulisan. Sementara itu, Tarigan (dalam Suladi 2000:14) memadankan kohesi dengan kepaduan dan koherensi dengan kerapian dan keteraturan.

Menurut Indiyastini (2006:39) berdasarkan wujud lingualnya kohesi dibedakan menjadi dua jenis, yaitu kohesi gramatikal dan kohesi leksikal. Peranti kohesi gramatikal meliputi kinjungsi, ellipsis, subsitusi, dan referensi. Peranti kohesi leksikal 
meliputi repetisi, sinonim, antonym, hiponim, dan kolokasi. Halliday dan Hasan (dalam Mulyana, 2005:26-27) juga mengemukakan hal yang sama bahwa unsur-unsur kohesi wacana dapat dibagi menjadi dua jenis, yaitu kohesi dan gramatikal dan kohesi leksikal. Unsur kohesi gramatikal terdiri atas referensi (reference), substitusi (substitution), ellipsis (ellipsis), dan konjungsi (conjunction), sedangkan kohesi leksikal terdiri atas pengulangan (repetisi), sinonim, antonim, hiponim, dan kolokasi (collocation). Senada dengan Halliday dan Hasan, Rani, dkk. (2006:97) menyatakan unsur kohesi terdiri atas unsur gramatikal dan leksikal. Dalam bahasa Inggris, hubungan gramatikal berdasarkan bentuk bahasa yang digunakan, misalnya referensi, substitusi, konjungsi, dan elipsis. Hubungan leksikal diciptakan dengan menggunakan bentuk-bentuk leksikal seperti reiterasi 'pengulangan' dan kolokasi 'sanding kata'. Kohesi gramatikal merupakan peranti atau penanda kohesi yang melibatkan penggunaan unsur-unsur kaidah bahasa. Peranti kohesi gramatikal meliputi (1) referensi 'pengacuan', (2) substitusi 'penggantian', dan (3) konjungsi 'kata penghubung'. Halliday dan Hasan (1976:33) membedakan referensi menjadi dua macam, endoforis dan eksoforis. Referensi eksoforis adalah pengacuan terhadap anteseden yang terrdapat di luar bahasa (ekatratekstual), seperti manusia hewan, alam sekitar, atau kegiatan pada umumnya. Referensi endoforis adalah pengacuan terhadap anteseden yang terdapat di dalam teks (intratekstual) dengan menggunakan pronomina, baik pronomina persona, pronomina demonstrativa, pronomina komparatif. Pengacu dan yang diacu adalah koreferensial. Referensi endoforis dibedakan menjadi (1) referensi anafora, dan (2) referensi katafora. Referensi anafora adalah pengacuan oleh pronomina terhadap anteseden yang terletak di kiri, dan sebaliknya referensi katafora adalah pengacuan pronomina terhadap anteseden yang terletak di kanan.

Referensi (penunjuk) merupakan bagian kohesi gramatikal yang berkaitan dengan penggunaan kata atau kelompok kata untuk menunjuk kata atau kelompok kata atau satuan gramatikal lainnya (Ramlan dalam Mulyana, 2005:27). Dalam konteks wacana, penunjuk (referensi) terbagi menjadi dua jenis, yaitu penunjuk eksoforik (di luar teks) dan penunjuk endoforik (di dalam teks). Dalam aspek referensi, terlihat adanya bentuk-bentuk pronomina (kata ganti orang, kata ganti tempat, dan kata ganti lainnya. Referensi endoforik terbagi dalam dua pola, yaitu anafora dan katafora. Unsur wacana yang menunjuk pada unsur lain yang telah disebutkan sebelumnya disebut sebagai anaforis

\section{METODE PENELITIAN}

Penelitian ini menggunakan jenis penelitian kualitatif. Menurut Moleong (2012:6) penelitian kualitatif adalah penelitian yang bermaksud untuk memahami fenomena tentang apa yang dialami oleh subjek penelitian. Pemilihan metode ini dikaitkan dengan tujuan penelitian, yakni mendeskripsikan secara intensif dan 
terperinci tentang penggunaan kohesi referensi pada naskah drama siswa kelas XI IPA dan IPS SMAN 2 Kandangan atau yang bertkaitan dengan objek kajian penelitian ini. Jadi, penelitian ini menggunakan pendekatan deskriptif analitis karena hasil dari peneltian ini berupa data deskriptif dalam bentuk kata tertulis.

Penelitian ini menggunakan naskah drama siswa kelas XI IPA dan IPS SMAN 2 Kandangan sebagai subjek penelitian. Teknik penentuan subjek didasarkan pada pengambilan sampel yang dilakukan secara random sampling. Dari beberapa kelas IPA dan IPS dipilihlah Kelas XI IPA dan kelas XI IPS sebagai subjek penelitian sebagai sampel. Adapun objek penelitiannya adalah penggunaan kohesi referensi pada naskah drama siswa tersebut.

Pengumpulan data yang digunakan dalam penelitian ini adalah metode simak dan teknik catat. Metode simak digunakan dengan cara peneliti membaca langsung naskah drama siswa kelas XI IPA1 dan kelas XI IPS 1 SMAN 2 Kandangan. Metode ini bertujuan untuk mendapatkan data secara konkret. Selanjutnya data yang diperoleh dicatat dalam karu data dengan menggunakan teknik catat (Sudaryanto, 1993:135). Sementara itu, teknik yang dilakukan dalam pengumpulan data adalah teknik catat. Peencatatan dilakukan terhadap penggunaan kohesi referensi. Teknik analisis data yang digunakan atau dilakukan dalam penelitian ini adalah teknik analisis deskriptif dengan kajian penggunaan kohesi referensi pada naskah drama siswa. Data berupa naskah drama dari siswa SMAN 2
Kandangan berjumlah 30 buah naskah drama. Data dipilih secara acak sehingga data yang diteliti berjumlah 18 buah naskah drama saja. Hal itu didasarkan pada anggapan bahwa setelah data dipilah dan dipilih ternyata naskah drama siswa SMAN 2 Kandangan yang dapat dijadikan sampel penelitian berjumlah 18 buah naskah yang terdiri atas 12 naskah siswa IPA dan 6 naskah siswa IPS.

\section{ANALISIS DAN PEMBAHASAN}

Dari 18 naskah drama yang dijadikan objek penelitian terdapat beberapa penggunaan kohesi referensi sebagai berikut.

\section{Kohesi Referensi Pronomina Persona}

Kohesi referensi pronomina adalah pronomina yang dipakai untuk mengacu pada orang. Pronomina persona terdiri atas persona orang pertama tunggal dan jamak, pronomina orang kedu tunggal dan jamak, dan pronomina orang ketiga tunggal dan jamak. Hal itu dapat kita lihat pada data berikut ini.

Data 1 (Tuturan 1)

Ancae: Eh, Roy kemana ya ? Kok dia gak masuk sekolah sih ? (1)

Alfin: Iya yah, gue juga gak tau. Jarang banget loh dia absen. Jangan - jangan dia kenapa napa lagi. (2)

Ancae: Kalau begitu nanti sehabis pulang sekolah, kita jenguk dia kerumahnya. Gimana? (3) 
Alfin: Oke. Eh, tapi kan hari ini kita ekskul English Club. Mungkin kita pulang jam 4 sore. (4)

(Alfian Huda, UNESCO)

Pada tuturan (1) terdapat kata dia yang termasuk persona orang ketiga tunggal. Bentuk dia pada kalimat Eh, Roy kemana ya? Kok dia gak masuk sekolah sih ? mengacu pada Roy, karena Roy adalah orang yang dibicarakan. Kata dia termasuk pengacuan endofora yang anaforis karena merujuk pada unsur yang disebutkan pada kalimat yang lebih dahulu atau mengacu pada satuan lingual yang mendahuluinya.

Pada tuturan (2) 'gue' termasuk referensi persona pertama tunggal. Kata gue pada tuturan (2) mengacu pada diri sendiri, yaitu Alfin. Alfin adalah orang yang melakukan tuturan tersebut. Kata gue merupakan persona endofora yang bersifat anafora (karena mengacu kepada satuan lingual yang disebutkan sebelumnya).

Kata kita pada tuturan (3) dan (4) merupakan referensi persona pertama jamak. Kata kita pada tuturan (3) dan (4) mengacu pada Ancae sebagai persona pertama dan Alfin sebagai persona kedua.

\footnotetext{
Data 1 (Tuturan 1)

Bayu: (Tertawa kecil) Kau ini, seperti anak-anak saja. (1)

Anisa: Hei! Aku bukan anak kecil, umurku sudah 17 tahun. Aku sudah dewasa! (Cemberut) (2)
}
Bayu: Tidak ada orang dewasa yang menyebut diri mereka sendiri dewasa. (3)
Anisa: Ah sudahlah, berhenti menggodaku! Lihat, gerbang sekolah sudah terlihat, cepat! (Mendorong punggung Bayu) (4)
Bayu: Kamu kenapa? Senyum- senyum terus dari tadi. (5) ................."
(Elma Dina Cahyani, UNESCO)

Pada tuturan (2) dan (4) kata 'Aku' dan ' $\mathbf{K u}$ ' termasuk kohesi gramatikal referensi persona orang pertama tunggal. Pemakaian 'Aku' pada kalimat Hei! Aku bukan anak kecil, umurku sudah 17 tahun dan ' $\mathbf{K u}$ ' dalam kalimat $A h$ sudahlah, berhenti menggodaku! Mengacu pada Anisa, karena Anisa adalah orang yang melakukan tuturan. 'Aku' dan 'ku memiliki persona endofora yang bersifat anafora (karena mengacu kepada satuan lingual yang disebutkan sebelumnya).

Pada tuturan (3), 'mereka' termasuk kohesi gramatikal referensi persona yang mengacu pada orang ketiga jamak. Bentuk 'mereka' pada kalimat Tidak ada orang dewasa yang menyebut diri mereka sendiri dewasa mengacu pada orang dewasa yang jumlahnya lebih dari satu. Bentuk 'mereka' memiliki persona endofora yang bersifat anafora (karena mengacu kepada satuan lingual yang mendahuluinya).

Pada tuturan (5), bentuk 'kamu' termasuk referensi kohesi gramatikal referensi persona orang kedua tunggal. Pemakaian 'kamu' pada kalimat Kamu kenapa? Senyum-senyum terus dari tadi mengacu pada Anisa, karena Anisa adalah orang yang diajak bicara oleh Bayu (lawan bicara Bayu). 'Kamu' 
memiliki persona endofora yang bersifat anafora (karena mengacu kepada satuan lingual yang mendahuluinya).

\section{Data 2 (Tuturan 7) \\ Anisa: Kau ini apa-apaan sih Yu! Bukannya dulu kau mendukung hubungan kami? Tapi kenapa sekarang kamu malah menyuruhku untuk putus dengannya?! (Meninggikan nada suaranya) (1)}

Bayu: Kak Retno itu brengsek Nis! Dia hanya - (2)

Anisa: (Menampar Bayu) Hentikan Yu! Dia nggak brengsek! Kamu ini kenapa? Datangdatang langsung mengatakan hal yang tidak baik tentangnya! (3)

Bayu: Nis, aku mengatakan hal ini juga untuk kebaikanmu! (Memegang pipinya yang ditampar) (4)

(Elma Dina Cahyani, UNESCO)

Pada tuturan (1), 'kami' merupakan penanda referensial persona yang berfungsi mempersonakan orang pertama jamak. Penanda referensial kami bersifat eksklusif, yaitu mengacu terhadap pembicara dan orang lain dipihaknya (orang pertama lebih dari satu orang), tidak mencakupi orangorang lain dipihak pendengar. 'Kami' pada kalimat Kau ini apa-apaan sih Yu! Bukannya dulu kau mendukung hubungan kami? pada tuturan (1) di atas mengacu pada Anisa dan orang lain di pihaknya, tidak mencangkupi orang-orang lain dipihak pendengar. Berdasarkan arah acuannya kalimat pada tuturan (1) tersebut bersifat anaforis.
Pada tuturan (3), 'kamu' merupakan penanda referensial persona yang berfungsi mempersonakan orang kedua tunggal. Bentuk 'kamu' termasuk persona orang kedua tunggal. Pemakaian 'kamu' pada kalimat Hentikan Yu! Dia nggak brengsek! Kamu ini kenapa? Datang-datang langsung mengatakan hal yang tidak baik tentangnya! mengacu pada Bayu, karena Bayu adalah orang yang diajak bicara. Kata kamu memiliki persona endofora yang bersifat anafora (karena mengacu kepada satuan lingual yang disebutkan sebelumnya). Sementara itu, bentuk nya pada kata tentangnya termasuk persona orang ketiga tunggal. Pemakaian (-nya) mengacu pada Retno, karena Retno adalah orang yang dibicarakan. Bentuk -nya memiliki persona endofora yang bersifat anafora (karena mengacu kepada satuan lingual yang mendahuluinya).

Data 1 (Tuturan 2)

Sintara: Bener tuh, gue aja bingung,
kenapa Galih mau deket
ama cewek kayak gitu!
Ihh" (Galih mendekat
kearah mereka) (1)

Arni: Dia mendeket tuh, pasti mau nyamperin gue ! (2)

Galih: Gue harap, kalian bisa jaga mulut kalian. ! kalian itu ngga tau apa-apa! (3)

Sintara: Uppzt, serem banget sih, ya udah, gue ngga banyak bicara deh. Sorry yah (4)

(M. Norhidayat Fahmi, UNESCO)

Pada tuturan (2) 'dia' merupakan penanda referensial persona yang 
berfungsi mempersonakan orang ketiga tunggal. Penanda referensial 'dia' pada kalimat Dia mendeket tuh, pasti mau nyamperin gue! mengacu pada (Galih), karena (Galih) adalah orang yang sedang dibicarakan. Dia memiliki persona endofora yang bersifat anafora (karena mengacu kepada satuan lingual yang mendahuluinya). Sementara itu, pada kalimat tersebut juga terdapat pronomina persona 'gue'. Gue 'saya' termasuk pronomina persona orang pertama tunggal. Pemakaian 'gue' mengacu pada Arni, karena Arni adalah orang yang melakukan tuturan. Gue memiliki persona endofora yang bersifat anafora (karena mengacu kepada satuan lingual yang disebutkan sebelumnya).

Pada tuturan (3) 'kalian' merupakan penanda referensial persona yang berfungsi mempersonakan orang kedua jamak. Penanda referensial 'kalian' pada kalimat Gue harap, kalian bisa jaga mulut kalian. ! kalian itu ngga tau apa-apa! mengacu pada Sintara dan Arni, (orang kedua yang jumlahnya lebih dari satu), karena keduanya adalah orang yang sedang diajak bicara oleh Galih . Kalian memiliki persona endofora yang bersifat anafora (karena mengacu kepada satuan lingual yang disebutkan sebelumnya).

\section{Data 1}

Pa Hamly: Kenapa kamu Nak ? (1)

Fathul: Tidak apa-apa Pa, saya lagi

kurang enak badan (2).

Pa Hamly: Kamu jangan bo'ong sama Bapak. Kalau kamu mau nangis, nangis aja dulu luapkan apa yang ingin kamu luapkan. (3)
(Fathul Zannah, UNESCO)

Pada tuturan (2) kata kurang termasuk kohesi gramatikal komparatif yang mengacu pada kadar kualitas atau intensitas yang kurang. Pada tuturan (2) kata kurang enak badan mengacu pada Fathul yang sedang sakit. Kata kurang tersebut mengacu pada kadar kualitas badan fathul yang tidak seperti biasanya.

Pada tuturan (1) dan (3), 'kamu' merupakan penanda referensial persona yang berfungsi mempersonakan orang kedua tunggal. Bentuk 'kamu' termasuk persona orang kedua tunggal. Pemakaian 'kamu' pada kalimat Kenapa kamu Nak ? dan Kamu jangan bo'ong sama Bapak. Kalau kamu mau nangis, nangis aja dulu luapkan apa yang ingin kamu luapkan mengacu pada Fathul, karena Fathul adalah orang yang diajak bicara oleh Pak Hamly. Bentuk 'kamu' memiliki persona endofora yang bersifat anafora (karena mengacu kepada satuan lingual yang disebutkan sebelumnya).

\section{Data 2}

Pa Hamly: Sabarlah Fathul, di dunia ini ada 3 yang tidak kita tau hanya sang pencipta yang tau yaitu, jodoh, rezky dan maut. Kedua orang tuamu bercerai mungkin jodoh mereka telah habis. (1)

Mendengar perkataan bapak Hamly, Fathul hanya terdiam.

Pa Hamly: Fathul, jadilah seperti karang di laut. Meski diterpa ombak ribuan 
tahun dia tidak hancur. (2)

Fathul Zannah (UNESCO)

Pada tuturan (1), 'mereka' merupakan penanda referensial persona yang berfungsi mempersonakan orang ketiga jamak. Bentuk 'mereka' termasuk persona orang ketiga jamak. Pemakaian (mereka) pada kalimat Kedua orangtuamu bercerai mungkin jodoh jodoh mereka telah habis. Kata mereka pada kalimat tersebut mengacu pada kedua orang tua Fathul, yaitu bapak dan ibu Fathul yang dijelaskan sebelumnya. Kata mereka termasuk persona endofora yang bersifat anafora (karena mengacu kepada satuan lingual yang disebutkan sebelumnya).

\section{Data 1 (Tuturan 6)}

Diandra : Eh? (memasang ekspresi bingung) Raditnya ada?

Rani: Ada, silahkan masuk kak Diandra. Langsung saja ke kamarnya.

Kak Diandra memang lebih cantik daripada di foto (melengkungkan senyum) (2)

Diandra: Terimakasih, ngomongngomong kau pasti adiknya Radit? Namamu siapa? (3)

Najma Amalia (UNESCO)

Pada tuturan (3), bentuk 'kau' termasuk persona orang kedua tunggal. Pemakaian kau pada kalimat Terimakasih, ngomong-ngomong kau pasti adiknya Radit? Namamu siapa? mengacu pada Rani (adik Radit), karena Rani adalah orang yang diajak bicara. Kau memiliki persona endofora yang bersifat anafora (karena mengacu kepada satuan lingual yang mendahuluinya).

\section{Data 1 (dialog 1)}

Bibi: Sayang, kamu harus mengerti. Ini adalah jalan yang sudah ditentukan Allah. Setiap pertemuan pasti akan berakhir dengan perpisahan. Kehidupan itu berputar sayang, kadang kita di atas, kadang juga kita di bawah. Dan sekarang mungkin Allah sedang menguji kita dengan perpisahan sementara. Kamu harus sabar. Suatu hari nanti Bibi yakin kita pasti akan bertemu lagi. Saat itu kamu dan Hardi sudah menjadi anak yang benar-benar matang dan dewasa. Yakinlah sayang. (Dengan wajah berkaca-kaca) (1)

Paman: Iya Bunga, benar kata Bibi. Walau pun Paman, Bibi, dan Hardi terpisah jauh dengan kamu tapi kami pasti akan selalu ingat dan mendo'akan kamu Nak. (2)

Bunga: Paman, Bibi, aku sayang kalian. (Memeluk Paman dan Bibi). (3)

(Nanda Rezki A., XI IPA 1)

Pada tuturan (1) 'kamu' merupakan penanda referensial persona yang berfungsi mempersonakan orang kedua tunggal. Bentuk 'kamu' termasuk persona orang kedua tunggal. Pemakaian 'kamu' Sayang, kamu harus 
mengerti. mengacu pada Bunga, karena Bunga adalah orang yang diajak bicara oleh Bibi. Kata 'kamu' memiliki persona endofora yang bersifat katafora (karena mengacu kepada satuan lingual yang disebutkan sesudahnya).

Pada tuturan (1) bentuk 'kita' termasuk persona orang pertama jamak. Pemakaian 'kita' pada kalimat Kehidupan itu berputar sayang, kadang kita diatas, kadang juga kita dibawah mengacu pada orang pertama jamak yang jumlahnya lebih dari satu (bibi, bunga, dan paman). Kita pada tuturan (1) termasuk persona endofora yang bersifat katafora (karena mengacu kepada satuan lingual yang disebutkan sesudahnya).

Pada tuturan (3) bentuk 'kalian' termasuk persona orang kedua jamak. Pemakaian 'kalian' pada kalimat Paman, Bibi, aku sayang kalian mengacu pada bibi dan paman (orang kedua lebih dari satu orang), karena bibi dan paman adalah orang yang diajak bicara oleh Bunga. Kalian pada tuturan (3) termasuk persona endofora yang bersifat anafora (karena mengacu kepada satuan lingual yang disebutkan sebelumnya).

Pada tuturan (2), 'kami' merupakan penanda referensial persona yang berfungsi mempersonakan orang pertama jamak. Penanda referensial 'kami' bersifat eksklusif, yaitu mengacu kepada pembicara dan orang lain dipihaknya, tidak mencangkupi orangorang lain dipihak pendengar. 'Kami' pada kalimat Walau pun Paman, Bibi, dan Hardi terpisah jauh dengan kamu tapi kami pasti akan selalu ingat dan mendo'akan kamu Nak di atas mengacu pada paman sebagai pembicara dan orang lain dipihaknya, yaitu Bibi dan Hardi.

\author{
Data 1 \\ " .................. \\ Mama: Rania, mama mau bicara \\ sama kamu. (1) \\ Rania: Ada apa Ma? (2) \\ Mama: Kamu nggak buat ulah lagi \\ kan disekolah? (3) \\ Rania: Enggak kok Ma. (4) \\ Mama: Kata Papa, dia mau bicara \\ padamu hari ini. (5) \\ Rania: Terus, sekarang Papanya \\ mana? (6) \\ Mama: Katanya masih dijalan. (7) \\ (Nurhidayati Fahrina, Kls X IPA 4)
}

Pada tuturan (1), 'kamu' merupakan penanda referensial persona yang berfungsi mempersonakan orang kedua tunggal. Penanda referensial 'kamu' bersifat eksklusif, yaitu mengacu kepada orang yang diajak bicara (lawan bicara). Kamu pada kalimat Rania, mama mau bicara sama kamu di atas mengacu pada Rania sebagai lawan bicara mama.

Pada tuturan (5), 'dia' merupakan bentuk persona orang ketiga tunggal. Pemakaian dia pada tuturan (5) di atas mengacu pada papa Rania, karena papa Rania adalah orang yang dibicarakan. Dia memiliki persona endofora yang bersifat anafora (karena mengacu kepada satuan lingual yang mendahuluinya).

\section{Data 1}

Fedi: Kay, kamu suka sama tempat ini? (1)

Kayla: Suka, suka banget malah Fed.

(tersenyum bahagia) (2) 
Fedi: Kay, aku mau ngomong sesuatu sama kamu.

(sambil memegang tangan Kayla) (3)

Kayla: (dengan wajah tersipu malu dan jantung berdegup kencang) (4)

Fedi: Kamu malam ini cantik banget Kay. Kamu itu beda dari cewe-cewe yang lain, dan aku ngerasain hal yang beda selama beberapa hari deket sama kamu. Dan aku udah nyimpen perasaan ini, dan aku rasa ini adalah saat yang tepat untuk aku ungkapin ke kamu. (dengan mata menatap tajam ke arah mata Kayla) (5)

(Norlaila Erleana S.M., UNESCO)

Pada tuturan (1) bentuk 'kamu' termasuk persona orang kedua tunggal. Pemakaian 'kamu' pada kalimat Kay, kamu suka sama tempat ini? dan Kamu malam ini cantik banget Kay mengacu pada Kayla, karena Kayla adalah orang yang diajak bicara Fedi. Kamu memiliki persona endofora yang bersifat anafora (karena mengacu kepada satuan lingual yang disebutkan sebelumnya).

\section{Data 1}

Sherly: Eh siapa tuh cowok liat deh. (1)

Kania: Mana? Oh iya, ganteng banget anak mana ya? (2)

Azizah: Kalian ini lupa ya dia itu kakak kelas kita SD dulu, kak Ridho Al- faqih. (3)

Kania: Oh my God, kok sekarang ganteng banget sih mau dong aku. (4)

Sherly: Jangan mimpi deh, dia tuh anak pondok selesai SD ngelanjutin sekolah ke pondok pesantren, lama gak pulang ke kampung wajar aja kita pangling. (5)

Kania: Mau gak ya dia sama aku?

(6)

(Nurmilawati, UNESCO)

Pada tuturan (3) bentuk 'kita' termasuk persona orang pertama jamak. Pemakaian 'kita' pada tuturan (3) mengacu pada Sherly, Kania, dan Azizah, karena Sherly, Kania, dan Azizah adalah orang yang terlibat dalam pembicaraan. 'Kita' pada tuturan (3) termasuk persona endofora yang bersifat anafora (karena mengacu kepada satuan lingual yang disebutkan sebelumnya).

Pada tuturan (3) bentuk 'kalian' termasuk persona orang kedua jamak. Pemakaian 'kalian' pada tuturan (3) mengacu pada Sherly dan Kania, karena Sherly dan Kania adalah orang yang diajak bicara Azizah. Kalian pada tuturan (3) termasuk persona endofora yang bersifat anafora (karena mengacu kepada satuan lingual yang disebutkan sebelumnya).

Pada tuturan (5) bentuk 'Dia' termasuk persona orang kedua tunggal. Pemakaian 'Dia' pada tuturan (5) mengacu pada Ridho Al-Faqih (cowok yang sedang dibicarakan). Dia pada tuturan (5) termasuk persona endofora yang bersifat anafora (karena mengacu kepada satuan lingual yang disebutkan sebelumnya).

Data 1 (babak 1) 
Rasya: Iya maaf. Kamu anak kelas mana? Kok bisa terlambat? (1)

Fina: Aku anak kelas 2 jurusan IPA. Iya nih, aku terlambat garagara tadi angkotnya mogok. Kamu sendiri anak kelas mana? Kok terlambat juga? (2)

Rasya: Aku anak kelas 3 jurusan IPS. Hehe, biasa lah yang namanya cowok (3)

Fina: Oh, kalo gitu kita sebelahan donk kelasnya (4)

(Muhammad Azmi Supian, Kelas X IPA I)

Pada tuturan (1) bentuk 'kamu' termasuk persona orang kedua tunggal. Pemakaian 'kamu' pada kalimat Iya maaf. Kamu anak kelas mana? mengacu pada Fina, karena Fina adalah orang yang diajak bicara Rasya. Kamu memiliki persona endofora yang bersifat katafora (karena mengacu kepada satuan lingual yang disebutkan sesudahnya).

Pada tuturan (2) terdapat pronomina persona pertama tunggal 'aku' yang mengacu pada unsur lain yang berada di dalam tuturan (teks) yang disebutkan sebelumnya. 'Aku' merupakan wujud dari penanda referensial endofora (acuannya berada di dalam teks), yang bersifat anaforis (acuannya disebutkan sebelumnya) melalui satuan lingual berupa pronomina persona pertama tunggal. Wujud penanda referensial 'aku' mengacu terhadap anteseden 'Fina' yang terletask di sebelah kiri, yaitu orang yang menuturkan tuturan tersebut.

Pada tuturan (4) bentuk 'Kita' termasuk persona orang pertama jamak.
Pemakaian 'Kita' pada tuturan (4) mengacu pada Rasya dan Fina, karena rasya dan Fina adalah orang yang terlibat dalam pembicaraan. Kita pada tuturan (4) termasuk persona endofora yang bersifat anafora (karena mengacu kepada satuan lingual yang disebutkan sebelumnya).

\section{Data 1 (babak 2)}

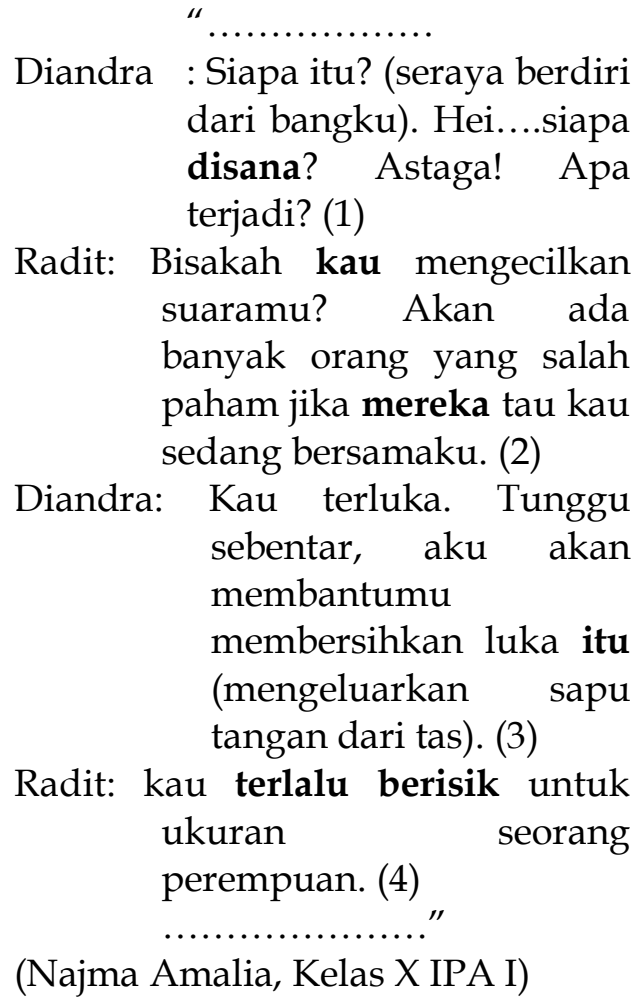

Pada tuturan (2) 'kau' termasuk persona orang kedua tunggal. Pemakaian ' $k a u$ ' mengacu kepada Diandra, karena Diandra adalah orang yang diajak bicara. Bentuk kau memiliki persona endofora yang bersifat anafora (karena mengacu kepada satuan lingual yang mendahuluinya). Sementara itu, 'mereka' termasuk persona orang ketiga jamak. Pemakaian mereka pada kalimat Akan ada banyak orang yang salah paham jika mereka tau kau sedang bersamaku. Mereka pada kalimat tersebut mengacu 
kepada orang-orang di luar Diandra dan Radit. Kata mereka termasuk persona endofora yang bersifat anaphora (karena mengacu kepada satuan lingual yang disebutkan sebelumnya.

Data 1
“..................
Dewi: Ada pa des, kok serius
banget. Kamu ada
masalah?? Ngomong aja
sama kita-kita (1)
Desita: Sebenarnya aku dah pengen
bilang dari tadi. Tapi aku
bingung harus
ngomongnya dari mana (2)
Anis: ga usah bingung des, kami ini
sahabat kamu jadi kami siap
buat kamu (3)
..................”

(Ice Trisnawati, Kelas XI IPS 2)

Bentuk $(A k u)$ termasuk persona I. Pemakaian (Aku) pada tuturan (2) mengacu pada (Desita), karena (Desita) adalah pembicara/orang yang berbicara dengan Dewi dan Anis. Aku termasuk persona endofora yang bersifat katafora.

Pada tuturan (3), 'kami' merupakan penanda referensial persona yang berfungsi mempersonakan orang pertama jamak. Penanda referensial 'kami' bersifat eksklusif yaitu mengacu kepada pembicara dan orang lain dipihaknya, tidak mencangkupi orangorang lain dipihak pendengar. 'Kami' pada tuturan (3) di atas mengacu pada Desita sebagai pembicara dan orang lain dipihaknya, yaitu Dewi dan Anis sebagai sahabat Desita.

Pada tuturan (3), 'kamu' merupakan penanda referensial persona yang berfungsi mempersonakan orang kedua tunggal. Penanda referensial 'kamu' bersifat eksklusif yaitu mengacu kepada orang yang diajak bicara (lawan bicara). Kamu pada tuturan (3) di atas mengacu pada Desita sebagai lawan bicara Anis.

Pada tuturan (1), 'kita-kita'(kita) merupakan penanda referensial persona yang berfungsi mempersonakan orang pertama jamak. Penanda referensial 'kita' bersifat eksklusif yaitu mengacu kepada orang yang berbicara bersama dengan orang lain termasuk yang diajak bicara. Kita pada tuturan (1) di atas mengacu pada Desita, Dewi, dan Anis.

\section{Data 1 (babak 1)}

Lala: Ren, sore ini kamu sibuk gak?

(1)

Rena: Nggak la (2)

Lala: Kalau kamu Si sibuk gak? (3)

Sisi: Nggak sibuk La. Emang kenapa La? (4)

Lala: Kita hari ini ngerjain tugas kelompok ya dirumah $\mathbf{k u}(5)$

(Aliah, Kelas XI IPS 2)

Pada tuturan (3) bentuk 'kamu' termasuk persona II. Pemakaian 'kamu' pada kalimat Kalau kamu Si sibuk gak? mengacu pada (Sisi), karena (Sisi) adalah orang yang di ajak bicara oleh Lala. Kamu pada tersebut termasuk persona endofora yang bersifat katafora (karena mengacu kepada satuan lingual yang disebutkan sesudahnya).

Pada tuturan (5) bentuk 'Kita' termasuk persona I jamak. Pemakaian 'kita' pada kalimat Kita hari ini ngerjain tugas kelompok ya dirumah $k u$ mengacu pada Lala dan Sisi, karena (Lala) dan (Sisi) adalah orang yang terlibat dalam pembicaraan. Kita pada kalimat tersebut termasuk persona endofora yang 
bersifat anafora (karena mengacu kepada satuan lingual yang disebutkan sebelumnya).

Pada tuturan (5) bentuk ' $\mathbf{k u}$ ' termasuk persona orangpertama tunggal. Pemakaian 'ku' pada kata dirumah ku dalam kalimat Kita hari ini ngerjain tugas kelompok ya di rumahku mengacu pada (Lala), karena (Lala) adalah orang yang berbicara pada Sisi. ' $\mathbf{K u}$ ' pada kata 'dirumah $\mathbf{k u}$ ' termasuk persona endofora yang bersifat anafora (karena mengacu kepada satuan lingual yang disebutkan sebelumnya).

\section{Kohesi Referensi Pronomina Demonstratif}

Kohesi pronomina demonstratif adalah pronomina penunjuk umum, pronomina penunjuk tempat, dan pronomina penunjuk hal ikhwal. Berikut ini data kohesi pronomina demonstratif.

\section{Data 1 (Tuturan 1)}

"...................

Ancae: Eh, Roy kemana ya ? Kok dia gak masuk sekolah sih ? (1)

Alfin: Iya yah, gue juga gak tau. Jarang banget loh dia absen. Jangan - jangan dia kenapa napa lagi. (2)

Ancae: Kalau begitu nanti sehabis pulang sekolah, kita jenguk dia kerumahnya. Gimana ? (3)

Alfin: Oke. Eh, tapi kan hari ini kita ekskul English Club. Mungkin kita pulang jam 4 sore. (4)

(Alfian Huda, UNESCO)
Pada tuturan (3) dan (4) terdapat referensi demonstratif, yaitu kata nanti dan hari ini. Kalimat Kalau begitu nanti sehabis pulang sekolah, kita jenguk dia kerumahnya. dalam tuturan (3) terdapat jenis penanda referensial demonstratif, yaitu dengan menggunakan pronomina penunjuk waktu 'nanti'. Nanti sehabis pulang sekolah merupakan penanda penunjukan yang acuannya berada di luar bahasa (teks) atau bersifat eksofora. Nanti yang diikuti keterangan sehabis pulang sekolah merujuk pada waktu yang ditentukan oleh si penutur, yaitu waktu setelah jam sekolah berakhir. Sementara itu, pada kalimat Oke. Eh, tapi kan hari ini kita ekskul English Club terdapat jenis penanda referensial demonstratif, yaitu dengan menggunakan pronomina penunjuk umum 'ini'. Hari ini merupakan penanda penunjukan yang acuannya berada di luar bahasa (teks) atau bersifat eksofora. Ini yang didahului nomina umum hari ini merujuk pada waktu yang ditentukan oleh si penutur.

\section{Data 2 (Tuturan 3) \\ Roy: ( Menahan rasa ingin menangis ) \\ Gue ngak tau apa yang harus gue lakuin buat ngebalas kebaikan elo di sisa-sisa waktu gue ini ? (1) \\ Ancae: Sisa - sisa waktu ? Tolong jangan ngomong yang ngawur dong ! (2)}

Roy: Elo tau kan, gue sering banget sakit kepala waktu kita bareng - bareng. Apalagi kalau kita lagi main game kesukaan kita, dota. Gue sering banget sakit kepala, makanya gue kurang bermain 
dengan baik. Terus, kemarin gue periksa ke dokter karna gue udah ga tahan, terus saat itu juga dokter nyuruh gue buat rontagen daerah kepala, dan tadi pagi gue ambil hasil rontagennya. (3)

(Alfian Huda, UNESCO)

Pada tuturan (3) kata sering, termasuk kohesi gramatikal demonstratif (penunjukkan) yang mengacu pada waktu, yaitu kerap kali atau acap kali. Kata sering pada kalimat Elo tau kan, gue sering banget sakit kepala waktu kita bareng - bareng. maksudnya adalah Roy yang kerap kali merasakan sakit kepala. Pada tuturan (3) terdapat kata kemarin yang termasuk kohesi gramatikal demonstratif yang mengacu pada waktu (satu hari sebelum hari ini).

Kata saat itu pada tuturan (3) termasuk kohesi gramatikal demonstratif, yaitu dengan menggunakan pronomina penunjuk umum 'itu'. Pengacuan yang dibentuk dengan pronomina penunjuk umum 'itu' berfungsi sebagai penanda referensial. Saat itu merupakan penanda penunjukan yang acuannya berada di luar bahasa (teks) atau bersifat eksofora. 'Itu' yang didahului keterangan saat itu mengacu pada waktu ketika itu juga. Kata tadi pagi pada tuturan (3) termasuk kohesi gramatikal yang juga menyatakan waktu, yaitu saat yang belum lama berlalu. Sementara itu, kata kurang pada tuturan (3) termasuk kohesi gramatikal komparatif perbandingan yang mengacu pada kadar kualitas atau intensitas yang kurang.
Data 2 (Dialog 7)

“.................

Anisa: Kau ini apa-apaan sih Yu! Bukannya dulu kau mendukung hubungan kami? Tapi kenapa sekarang kamu malah menyuruhku untuk putus dengannya?! (Meninggikan nada suaranya) (1)

Bayu: Kak Retno itu brengsek Nis! Dia hanya - (2)

Anisa: (Menampar Bayu) Hentikan Yu! Dia nggak brengsek! Kamu ini kenapa? Datangdatang langsung mengatakan hal yang tidak baik tentangnya! (3)

Bayu: Nis, aku mengatakan hal ini juga untuk kebaikanmu!

(Memegang pipinya yang ditampar) (4)

(Elma Dina Cahyani, UNESCO)

Pada tuturan (1) kata 'dulu' dan 'sekarang' merupakan penanda referensial demonstratif yang mengacu pada waktu. Kata 'dulu' pada kalimat Kau ini apa-apaan sih Yu! Bukannya dulu kau mendukung hubungan kami? mengacu pada waktu yang telah lalu, sedangkan kata sekarang pada kalimat Tapi kenapa sekarang kamu malah menyuruhku untuk putus dengannya? mengacu pada waktu saat ini. Pada tuturan (4) terdapat jenis penanda referensial demonstratif, yaitu dengan menggunakan pronomina penunjuk umum 'ini'. Pengacuan yang dibentuk dengan pronomina penunjuk 'ini' pada tuturan (4) di atas berfungsi sebagai penanda referensial. Hal ini merupakan penanda penunjukan yang acuannya berada di luar bahasa (teks) atau bersifat 
eksofora. Ini yang didahului nomina umum hal ini merujuk pada sesuatu masalah yang sedang dibicarakan.

\section{Data 1 (Dialog 5)}

Ayah Fina: Nak Rasya, cepat kesini sekarang ya nak, Fina sakit nak. Dia muntah darah dan mimisan. (1)

Rasya: Ha? Kok bisa gitu pak? Emangnya Fina habis ngapain? (2)

Ayah Fina: Bapak nggak tau nak, mending kamu kesini sekarang nak. (3)

Rasya: Iya pak, sekarang saya akan kesana. (4)

(M. Azmi Supian, UNESCO)

Pada tuturan (1) dan (4) kata kesini dan kesana termasuk kohesi gramatikal demonstratif yang mengacu pada tempat. Kata kesini pada kalimat Nak Rasya, cepat kesini sekarang ya nak, Fina sakit nak. Dia muntah darah dan mimisan mengacu pada tempat atau lokasi yang dekat dengan pembicara, sedangkan kesana pada kalimat Iya pak, sekarang saya akan kesana mengacu pada tempat atau lokasi yang jauh dari pembicara. Sementara itu, kata sekarang pada tuturan (1) dan (4) termasuk kohesi gramatikal demonstratif yang mengacu pada waktu kini.

Data 1 (Tuturan 6)
“.....................
Diandra: $\begin{aligned} & \text { Kurasa ini rumahnya } \\ & \text { (sambil menekan bel) (1) }\end{aligned}$
Rani: $\quad \begin{aligned} & \text { (membuka pintu) Kak } \\ & \text { Diandra? (2) }\end{aligned}$

Diandra: Eh? (memasang ekspresi bingung) Raditnya ada?

Rani: Ada, silahkan masuk kak Diandra. Langsung saja ke kamarnya.

Kak Diandra memang lebih cantik daripada di foto (melengkungkan senyum)

(4)

(Najma Amalia, UNESCO)

Pada tuturan (1) terdapat jenis penanda referensial demonstratif, yaitu dengan menggunakan penunjuk umum 'ini'. Pengacuan yang dibentuk dengan penunjuk umum 'ini' berfungsi sebagai penanda referensial. Ini rumahnya merupakan penanda penunjukan yang acuannya berada di luar bahasa (teks) atau bersifat eksofora. Ini yang diikuti nomina rumah merujuk pada suatu tempat yang berbentuk rumah. Sementara itu, bentuk -nya termasuk persona orang ketiga tunggal. Pemakaian -nya pada rumahnya mengacu pada Radit, karena Radit adalah orang yang dibicarakan. Bentuk -nya memiliki persona endofora yangt bersifat anaphora (karena mengacu pada satuan lingual yang mendahuluinya).

Data 2 (Tuturan 8)

Diandra: Mmm... kamu ingat gak, ini hari apa? (1)

Radit: Hari ini hari Kamis, kan? (2)

Diandra: Ish... masa kamu lupa, sih (wajah cemberut). Pokoknya aku tunggu kamu di taman biasa malam ini. (3) 
(Najma Amalia, UNESCO)

Pada tuturan (2) dan (3) terdapat jenis penanda referensial demonstratif, yaitu dengan menggunakan penunjuk umum 'ini'. Pengacuan yang dibentuk dengan penunjuk umum 'ini' berfungsi sebagai penanda referensial. Hari ini dan malam ini merupakan penanda penunjukan yang acuannya berada di luar bahasa (teks) atau bersifat eksofora. Ini yang didahului keterangan hari merujuk pada hari yang ditanyakan oleh Radit, sedangkan ini yang didahului keterangan malam merujuk pada waktu yang ditentukan Diandra untuk bertemu dengan Radit.

\section{Data 1 (Tuturan)}

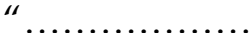

Bibi: Sayang, kamu harus mengerti. Ini adalah jalan yang sudah ditentukan Allah. Setiap pertemuan pasti akan berakhir dengan perpisahan. Kehidupan itu berputar sayang, kadang kita diatas, kadang juga kita dibawah. Dan sekarang mungkin Allah sedang menguji kita dengan perpisahan sementara. Kamu harus sabar. Suatu hari nanti Bibi yakin kita pasti akan bertemu lagi. Saat itu kamu dan Hardi sudah menjadi anak yang benar-benar matang dan dewasa. Yakinlah sayang. (Dengan wajah berkaca-kaca) (1)

Paman: Iya Bunga, benar kata Bibi. Walau pun Paman, Bibi, dan Hardi terpisah jauh dengan kamu tapi kami pasti akan selalu ingat dan mendo'akan kamu Nak.
(Nanda Rezki A., XI IPA 1)

Pada tuturan (1) terdapat jenis penanda referensial demkonstratif, yaitu dengan menggunakan penunjuk ' di' dan 'sekarang'. Pengacuan yang dibentuk dengan pro0nomina penunjuk 'di' berfungsi sebagai penanda referensial. Di bawah dan di atas merupakan penanda penunjukan yang acuannya berada di luar bahasa (teks) atau bersifat eksofora. Di yang diikuti keterangan atas dan bawah merujuk pada tempat secara eksplisit. Sementara itu, kata sekarang merupakan penanda referensial demonstratif yang mengacu pada waktu saat ini.

Data 1
Mama: Rania, mama mau bicara
sama kamu. (1)
Rania: Ada apa Ma? (2)
Mama: Kamu nggak buat ulah lagi
$\quad$ kan disekolah? ( 3$)$
Rania: Enggak kok Ma. (4)
Mama: Kata Papa, dia mau bicara
$\quad$ padamu hari ini. (5)
Rania: Terus, sekarang Papanya
$\quad$ mana? (6)
Mama: Katanya masih dijalan. (7)
$\quad$...................”
(Nurhidayati Fahrina, Kls X IPA 4)

Pada tuturan (3) dan (7) terdapat jenis penanda referensial demonstratif, yaitu dengan menggunakan penunjuk umum 'di'. Pengacuan yang dibentuk dengan pronomina penunjuk umum 'di' berfungsi sebagai penanda referensial. Di sekolah dan di jalan merupakan penanda penunjukan yang acuannnya berada di luar bahasa (teks) atau bersifat eksofora. Di yang diikuti keterangan 
sekolah dan jalan merujuk pada tempat yang disebutkan mama Rania

Pada tuturan (5) terdapat jenis penanda referensial demonstratif, yaitu dengan menggunakan penunjuk umum 'ini'. Pengacuan yang dibentuk dengan pronomina penunjuk umum 'ini' berfungsi sebagai penanda referensial. Hari ini merupakan penanda penunjukan yang acuannnya berada di luar bahasa (teks) atau bersifat eksofora. Ini yang didahului keterangan hari merujuk pada waktu yang ditentukan papa untuk bicara dengan Rania.

Pada tuturan (6) terdapat jenis penanda referensial demonstratif, yaitu dengan menggunakan penunjuk 'sekarang'. Sekarang merupakan penanda referensial demonstratif yang mengacu pada waktu kini.

\section{Data 2}

Rania: Jadi maksud mama aku (1)

Mama: Tidak begitu Rania, maksud mama lebih bersifat seperti anak gadis, bukan seperti anak lelaki yang suka berantem. (2)

Rania: Ummm, akan Rania coba. Rania mau kekamar dulu ya, mau bobo. (3)

(Nurhidayati Fahrina, Kls X IPA 4)

Pada tuturan (3) terdapat jenis penanda referensial demonstratif, yaitu dengan menggunakan pronomina penunjuk umum 'ke'. Pengacuan yang dibentuk dengan pronomina penunjuk umum 'ke' pada tuturan (4) di atas sebagai penanda referensial. Ke kamar merupakan penanda penunjukan yang acuannya berada di luar bahasa (teks) atau bersifat eksofora. Ke yang diikuti keterangan tempat kamar merujuk pada tempat di mana Rania akan beristirahat.

\section{Data 1}

Fedi: Kay, kamu suka sama tempat ini? (1)

Kayla: Suka, suka banget malah Fed.

(tersenyum bahagia) (2)

Fedi: Kay, aku mau ngomong sesuatu sama kamu. (sambil memegang tangan Kayla) (3)

Kayla: (dengan wajah tersipu malu dan jantung berdegup kencang) (4)

Fedi: Kamu malam ini cantik banget Kay. Kamu itu beda dari cewe-cewe yang lain, dan aku ngerasain hal yang beda selama beberapa hari deket sama kamu. Dan aku udah nyimpen perasaan ini, dan aku rasa ini adalah saat yang tepat untuk aku ungkapin ke kamu. (dengan mata menatap tajam ke arah mata Kayla) (5)

\section{(Norlaila Erleana S.M., UNESCO)}

Pada tuturan (1) dan (5) terdapat jenis penanda referensial demonstratif, yaitu dengan menggunakan penunjuk umum 'ini'. Pengacuan yang dibentuk dengan penunjuk umum 'ini' berfungsi sebagai penanda referensial. Tempat ini dan malam ini merupakan penanda penunjukan yang acuannya berada di luar bahasa (teks) atau bersifat eksofora. Ini yang didahului keterangan tempat merujuk pada tempat yang ditunjuk 
oleh Fedi, sedangkan ini yang didahului keterangan malam mengacu pada waktu Fedi dan Kayla bertemu.

\section{Data 1}

Kania: Oh my God, kok sekarang ganteng banget sih mau dong aku. (1)

Sherly: Jangan mimpi deh, dia tuh anak pondok selesai SD ngelanjutin sekolah ke pondok pesantren, lama gak pulang ke kampung wajar aja kita pangling. (2)

Kania: Mau gak ya dia sama aku? (3)

Sherly: Ya enggak lah, dia pasti nyari yang selevel minimal yang pakai kerudung ah kita? Boro-boro pakai kerudung, ke mesjid baru pakai kerudung. (4)

(Nurmilawati, UNESCO)

Pada tuturan (1) dan (4) terdapat jenis penanda referensial demonstratif, yaitu dengan menggunakan pronomina penunjuk umum 'ke'. Pengacuan yang dibentuk dengan pronomina penunjuk umum ' $\mathbf{k e}^{\prime}$ pada tuturan (1) dan (4) di atas sebagai penanda referensial. Ke Pondok Pesantren merupakan penanda penunjukan yang acuannya berada di luar bahasa (teks) atau bersifat eksofora.

Ke Pondok Pesantren dan ke Mesjid menunjuk pada tempat secara eksplisit (Pondok Pesantren dan Mesjid).

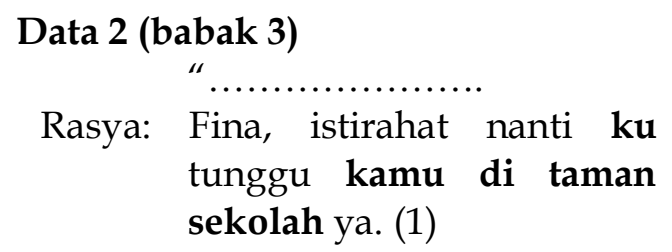

Fina: Ada apa, kok tiba-tiba ngajak ke taman sekolah? (2)

Rasya: Ada deh, pokoknya kamu datang aja kesana (3)

(Muhammad Azmi Supian, Kelas X IPA 1)

Pada tuturan (1) bentuk (-ku) termasuk persona orang pertama tunggal. Pemakaian (-ku) mengacu pada Rasya, karena Rasya adalah orang yang berbicara pada Fina. Bentuk (-ku) memiliki persona endofora yang bersifat katafora (karena mengacu kepada satuan lingual yang disebutkan sesudahnya).

Pada tuturan (1) bentuk 'kamu' termasuk persona orang kedua tunggal. Pemakaian 'kamu' mengacu pada Fina, karena Fina adalah orang yang diajak bicara Rasya. Bentuk 'kamu' memiliki persona endofora yang bersifat katafora (karena mengacu kepada satuan lingual yang disebutkan sesudahnya).

Pada tuturan (1) dan (2) terdapat jenis penanda referensial demkonstratif, yaitu dengan menggunakan penunjuk umum 'di' dan 'ke'. Pengacuan yang dibentuk dengan pro0nomina penunjuk umum 'di' dan ' $k \mathrm{e}^{\prime}$ berfungsi sebagai penanda referensial. Di taman sekolah dan ke taman sekolah merupakan penanda penunjukan yang acuannya berada di luar bahasa (teks) atau bersifat eksofora. Di dan ke yang diikuti keterangan taman sekolah merujuk pada tempat di mana Rasya menunggu Fina.

Pada tuturan (3) kata kesana termasuk kohesi gramatikal demonstratif yang mengacu pada tempat. Kata kesana mengacu pada tempat atau lokasi yang jauh dari pembicara. Kesana pada tuturan (3) 
mengacu pada taman sekolah yang menjadi tempat bertemunya Rasya dan Fina.

\author{
Data 1 (babak 2) \\ Diandra : Siapa itu? (seraya berdiri \\ dari bangku). Hei....siapa \\ disana? Astaga! Apa \\ terjadi? (1) \\ Radit: Bisakah kau mengecilkan \\ suaramu? Akan ada \\ banyak orang yang salah \\ paham jika mereka tau kau \\ sedang bersamaku. (2) \\ Diandra : Kau terluka. Tunggu \\ sebentar, aku akan \\ membantumu \\ membersihkan luka itu \\ (mengeluarkan sapu \\ tangan dari tas). (3) \\ Radit: kau terlalu berisik untuk \\ ukuran seorang \\ perempuan. (4) \\ Najma Amalia (Kelas X IPA I)
}

Pada tuturan (1) kata di sana termasuk kohesi gramatikal demonstratif (penunjukan) yang mengacu pada tempat yang letaknya agak jauh. Pada tuturan (3) terdapat jenis penanda referensial demonstratif, yaitu dengan menggunakan penunjuk umum 'itu'. Pengacuan yang dibentuk dengan penunjuk umum 'itu' berfungsi sebagai penanda referensial. Luka itu merupakan penanda penunjukan yang acuannya berada di luar bahasa (teks) atau bersifat eksofora. Itu yang didahului keterangan luka merujuk pada sesuatu yang dialami Radit.

\section{Data 2 (babak 12)}

Rani: Sebenarnya, beberapa jam yang lalu. Kak Radit pulang kerumah untuk menitipkan ini. (menyerahkan sepucuk surat). Keadaannya sudah sangat parah saat kak Radit sampai dirumah, ditambah penyakit leukemia yang dideritanya. Kak Radit...sangat mencintai kak Diandra...(wajah murung) (1)

Diandra: Leukemia? Sejak kapan? (terisak) (2)

Rani: 3 tahun yang lalu, hidup kak Radit seolah redup begitu saja. Tapi....semenjak kak Diandra datang. Hidup kak Radit kembali dipenuhi oleh sinar terang. Kak Diandra, adalah cahaya untuknya...(3)

(Najma Amalia, Kelas X IPA I)

Pada tuturan (1) terdapat jenis penanda referensial demkonstratif, yaitu dengan menggunakan penunjuk 'ke'. Pengacuan yang dibentuk dengan pronomina penunjuk ' $k e^{\prime}$ berfungsi sebagai penanda referensial. Ke rumah merupakan penanda penunjukan yang acuannya berada di luar bahasa (teks) atau bersifat eksofora. Ke yang diikuti keterangan rumah merujuk pada tempat di mana Radit tinggal.

\section{Data 1 (babak 5) \\ " \\ Arni: Ada cewek yang dari dulu suka ama lo lih, yang diam- diam ngebantuin lo, yang diam-diam ada dibelakang lo. Yang diam-diam selalu jadi pendukung lo. Tapi lo}


ngga pernah sadar kalo dia itu pernah ada. Lo bahkan cuma nganggap orang itu pengganggu yang ngga semestinya ada disamping lo.(1)

Galih: Gue makin ngga ngerti! (heran) (2)

Arni: Cewek itu, ada disekitar lo. Yang apapun keadannya, akan slalu ada buat lo! Awalnya, dia memang benci, ngeliat lo ma orang lain, cemburu bahkan marah, kesal. Tapi, kedewasaan udah mengajarkan gadis itu, kalau cinta, tak selamanya harus memiliki. Cinta juga bukan keegoisan untuk memiliki. Cinta itu sesuatu untuk direlakan. Seperti saat ini, gadis itu, telah menenangkan hatinya. Membiarkan orang yang ia sukai pergi dengan orang lain. (3)

(M. Norhidayat Fahmi, Kelas XI IPA I UNESCO)

Pada tuturan (1) dan (3) terdapat jenis penanda referensial demkonstratif, yaitu dengan menggunakan penunjuk 'di'. Pengacuan yang dibentuk dengan pro0nomina penunjuk 'di' berfungsi sebagai penanda referensial. Di belakang, di samping, dan di sekitar merupakan penanda penunjukan yang acuannya berada di luar bahasa (teks) atau bersifat eksofora. Di yang diikuti keterangan belakang, samping, dan sekitar merujuk pada tempat secara eksplisit.

Pada tuturan (2) dan (3) kata sekarang dan kemarin merupakan penanda referensial demonstratif yang mengacu pada waktu. Kata sekarang merupakan penanda referensial demonstratif waktu yang mengacu pada waktu kini, sedangkan kemarin merupakan penanda referensial demonstratif waktu yang mengacu pada waktu lampau.

\section{Data 1 (babak 1)}

“

Lala: Ren, sore ini kamu sibuk gak?

(1)

Rena: Nggak la (2)

Lala: Kalau kamu Si sibuk gak? (3)

Sisi: Nggak sibuk La. Emang kenapa La? (4)

Lala: Kita hari ini ngerjain tugas kelompok ya dirumah $\mathrm{ku}(5)$

(Aliah, Kelas XI IPS 2)

Pada tuturan (1) dan (5) terdapat jenis penanda referensial demonstratif, yaitu dengan menggunakan pronomina penunjuk umum 'ini'. Pengacuan yang dibentuk dengan pronomina penunjuk umum 'ini' pada tuturan (1) dan (5) di atas sebagai penanda referensial. Sore ini dan hari ini merupakan penanda penunjukan yang acuannya berada di luar bahasa (teks) atau bersifat eksofora. Ini yang didahului nomina umum sore ini dan hari ini merujuk pada waktu yang ditentukan oleh Lala untuk mengerjakan tugas kelompok.

\section{Kohesi Referensi Komparatif}

Kohesi referensi komparatif adalah kohesi referensi yang menyatakan perbandingan unsure yang satu dengan yang lain. Kohesi referensi komparatif terdiri atas kohesi referensi komparatif yang menyatakan kurang, kohesi 
referensi komparatif yang menyatakan sama, dan kohesi referensi komparatif yang menyatakan lebih. Berikut ini data kohesi refernsi komparatif dalam naskah drama siswa SMAN 2 Kandangan.

\section{Data 1 (Tuturan 1) \\ Bayu: (Tertawa kecil) Kau ini, seperti anak-anak saja. (1)}

Anisa: Hei! Aku bukan anak kecil, umurku sudah 17 tahun. Aku sudah dewasa! (Cemberut) (2)

Elma Dina Cahyani, UNESCO)

Pada tuturan (1) kata seperti termasuk kohesi gramatikal komparatif (perbandingan). Kata seperti pada kalimat Kau ini, seperti anak-anak saja membandingkan dua hal yang mempunyai kemiripan atau kesamaan dari segi sikap, sifat, watak, dan perilaku Anisa yang dikatakan seperti anak-anak.

\section{Data 1 (Tuturan 2)}

Sintara: Bener tuh, gue aja bingung, kenapa Galih mau deket ama cewek kayak gitu! Ihhh" (Galih mendekat kearah mereka) (1)

Arni: Dia mendeket tuh, pasti mau nyamperin gue ! (2)

Galih: Gue harap, kalian bisa jaga mulut kalian. ! kalian itu ngga tau apa-apa! (3)

Sintara: Uppzt, serem banget sih, ya udah, gue ngga banyak bicara deh. Sorry yah (4)

(M. Norhidayat Fahmi, UNESCO)
Pada tuturan (1) kata kayak (seperti) termasuk kohesi gramatikal komparatif (perbandingan). Satuan lingual kayak (seperti) pada kalimat Bener tuh, gue aja bingung, kenapa Galih mau deket ama cewek kayak gitu! Ihhh" pada tuturan (1) mengacu pada perbandingan persamaan bisa dari fisik, tingkah laku, atau perilaku dari cewek yang sedang dibicarakan. Pada tuturan (4) terdapat penanda referensial yang berupa bentuk komparatif banget (sangat)....pada kalimat Uppzt, serem banget sih. Maksud yang dibandingkan jelas dan dipahami, dimana Galih terlihat begitu marah ketika sinta dan Arni membicarakan cewek yang sedang dekat dengannya. Kemarahan Galih terlihat menyeramkan sekali sehingga membuat sintara ketakutan. Berdasarkan sifatnya maka penanda referensial ini bersifat eksoforis.

\section{Data 1}

Pa Hamly: Kenapa kamu Nak ? (1)

Fathul: Tidak apa-apa Pa, saya lagi kurang enak badan (2) "

(Fathul Zannah, UNESCO)

Pada tuturan (2) kata kurang termasuk kohesi gramatikal komparatif yang mengacu pada kadar kualitas atau intensitas yang kurang. Pada tuturan (2) kata kurang enak badan mengacu pada Fathul yang sedang sakit. Kata kurang tersebut mengacu pada kadar kualitas badan fathul yang tidak seperti biasanya. 


\section{Data 2}

$\begin{aligned} & \text { Pa Hamly: } \text { Sabarlah Fathul, di dunia } \\ & \text { ini ada } 3 \text { yang tidak kita } \\ & \text { tau hanya sang pencipta } \\ & \text { yang tau yaitu, jodoh, } \\ & \text { rezky dan maut. Kedua } \\ & \text { orang tuamu bercerai } \\ & \text { mungkin jodoh mereka } \\ & \text { telah habis. (1) } \\ & \text { Mendengar perkataan } \\ & \text { bapak Hamly, Fathul } \\ & \text { hanya terdiam. }\end{aligned}$

Pa Hamly: Fathul, jadilah seperti karang di laut. Meski diterpa ombak ribuan tahun dia tidak hancur. (2)

Fathul: Iya Pak, makasih. (3)

(Fathul Zannah, UNESCO)

Pada tuturan (2) kata seperti termasuk kohesi gramatikal komparatif (perbandingan). Satuan lingual seperti pada kalimat Fathul, jadilah seperti karang di laut. Meski diterpa ombak ribuan tahun dia tidak hancur mengacu pada perbandingan persamaan antara kekuatan karang (di laut) yang tidak mudah hancur meski diterpa ombak dengan kekuatan dan kesabaran Fathul dalam menghadapi segala cobaan dalam hidupnya.

\section{Data 1 (Dialog 6) \\ Diandra: Kurasa ini rumahnya (sambil menekan bel) (1) \\ Rani: (membuka pintu) Kak Diandra? (2)}

Diandra: Eh? (memasang ekspresi bingung) Raditnya ada? (3)
Rani: Ada, silahkan masuk kak Diandra. Langsung saja ke kamarnya.

Kak Diandra memang lebih cantik daripada di foto (melengkungkan senyum) (4)

(Najma Amalia, UNESCO)

Pada tuturan (4) terdapat penanda referensial yang berupa bentuk komparatif lebih...pada kalimat Kak Diandra memang lebih cantik daripada di foto. Maksud yang dibandingkan jelas dan bisa dipahami, bahwa Diandra lebih cantik apabila dilihat langsung dibandingkan dengan yang ada di foto. Berdasarkan sifatnya maka penanda referensial ini bersifat eksoforis.

\section{Data 2}

$$
\begin{aligned}
& \text { Mama: (Menyela) Maksud Papa } \\
& \text { kamu sudah remaja dan } \\
& \text { sudah seharusnya menata } \\
& \text { diri kamu menjadi lebih } \\
& \text { baik seperti anak-anak } \\
& \text { gadis normal lainnya. (1) } \\
& \text { Rania: Jadi maksud mama aku } \\
& \text { bukan anak yang normal? } \\
& \text { (2) } \\
& \text { Mama: Tidak begitu Rania, maksud } \\
& \text { mama lebih bersifat seperti } \\
& \text { anak gadis, bukan seperti } \\
& \text { anak lelaki yang suka } \\
& \text { berantem. (3) } \\
& \text {.................... }
\end{aligned}
$$

Pada tuturan (1) terdapat kata seperti yang termasuk kohesi gramatikal komparatif (perbandingan). Satuan lingual seperti pada kalimat Maksud Papa kamu sudah remaja dan sudah seharusnya menata diri kamu menjadi lebih 
baik seperti anak-anak gadis normal lainnya bersifat membandingkan dua hal atau lebih yang mempunyai kemiripan atau kesamaan dari segi bentuk/wujud, sikap, sifat, watak, perilaku, dan sebagainya. Pada kalimat tersebut mama Rania mengharapkan anaknya mempunyai sikap, sifat, watak, dan perilaku seperti anak-anak gadis normal lainnya. Sementara itu, pada kalimat Tidak begitu Rania, maksud mama lebih bersifat seperti anak gadis, bukan seperti anak lelaki yang suka berantem pada tuturan (3) mama Rania mengharapkan Rania lebih bersifat seperti anak perempuan dan bukan bersifat seperti anak laki-laki.

\section{Data 1}

Sherly: Eh siapa tuh cowok liat deh.

(1)

Kania: Mana? Oh iya, ganteng banget anak mana ya? (2)

Azizah: Kalian ini lupa ya dia itu kakak kelas kita SD dulu, kak Ridho Al- faqih. (3) ................"

(Nurmilawati, UNESCO)

Pada tuturan (2) terdapat penanda referensial yang berupa bentuk komparatif 'banget' (sangat)....pada kalimat Mana? Oh iya, ganteng banget anak mana ya? Maujud yang dibandingkan jelas dan dipahami, Kania melihat seorang cowok yang sangat ganteng. 'Banget' pada kalimat tersebut mengacu ke kadar kualitas atau intensitas (wajah seorang cowok) yang paling tinggi di antara adjektiva yang dibandingkan. Berdasarkan sifatnya maka penanda referensial ini bersifat eksoforis.
Data 2 (babak 12)

"

Rani: Sebenarnya, beberapa jam yang lalu. Kak Radit pulang kerumah untuk menitipkan ini. (menyerahkan sepucuk surat). Keadaannya sudah sangat parah saat kak Radit sampai dirumah, ditambah penyakit leukemia yang dideritanya. Kak Radit...sangat mencintai kak Diandra...(wajah murung) (1)

Diandra: Leukemia? Sejak kapan? (terisak) (2)

Rani: 3 tahun yang lalu, hidup kak Radit seolah redup begitu saja. Tapi....semenjak kak Diandra datang. Hidup kak Radit kembali dipenuhi oleh sinar terang. Kak Diandra, adalah untuknya...(3) cahaya ......................."

(Najma Amalia, Kelas XI IPA I)

Pada tuturan (1) terdapat penanda referensial yang berupa bentuk komparatif sangat. Kata sangat pada kalimat Keadaannya sudah sangat parah saat kak Radit sampai dirumah, ditambah penyakit leukemia yang dideritanya dan Kak Radit...sangat mencintai kak Diandra... mengacu ke kadar kualitas atau intensitas yang paling tinggi. Pada kalimat tersebut maksud yang dibandingkan jelas dan dipahami, penyakit Radit sudah begitu parah dan Radit begitu mencintai Diandra. Berdasarkan sifatnya maka penanda referensial ini bersifat eksoforis. 


\section{Data 1 (babak 2)}
Momo: Yes, gua tuntas ulangan sejarah...(1)
Onyet: Waduh, baru dapet nilai rata-rata aja bangga, kayak gue dong...(2)

Momo: Lo dapet nilai berapa emang? (3)

Onyet: 76, dong. (4)

Momo: Monyet lo, Cuma beda satu juga (5)

Onyet: Weiits,...yang penting gue lebih tinggi dari lo, hahaha...(6)

(Satyawan Anshary, Kelas XI IPA I)

Kata 'Kayak' termasuk kohesi gramatikal komparatif (perbandingan) yang mengacu ke kadar kualitas atau intensitas yang sama atau mirip. Pada tuturan (2) kata 'kayak' (seperti) mengacu ke kadar kualitas atau intensitas sama, di mana Onyet menginginkan nilai ulangan yang diperoleh momo sama seperti nilai ulangan yang diperolehnya.

Pada tuturan (6) terdapat penanda referensial yang berupa bentuk komparatif 'lebih' pada kalimat Weiits,...yang penting gue lebih tinggi dari lo, hahaha... Kata 'lebih' pada kalimat tersebut mengacu ke kadar kualitas atau intensitas yang lebih atau yang kurang. Kata 'lebih' mengacu ke kadar kualitas atau intensitas yang lebih, di mana nilai ulangan yang diperoleh dari Onyet lebih tinggi dibandingkan nilai yang diperoleh Momo. Berdasarkan sifatnya maka penanda referensial ini bersifat eksoforis.

\section{Data 1 (babak 4) \\ Bunga: Hardiiii..., aku dapat ikannya. Yang ini lebih besar (berteriak gembira) (1) \\ Hardi: (Berlari-lari) Mana- mana...wahh kamu hebat juga yaah. (2) \\ Bunga: Iya dong. Nggak kayak kamu tuh payah, ngga dapat-dapat. Haha (3) \\ Hardi: Yeee...kamu dipuji malah ngatain aku lagi. Tunggu aja ya aku pasti dapat ikan yang lebih besar lagi. (4)}

(Nanda Rezki A., Kelas XI IPA 1)

Kata 'Kayak' termasuk kohesi gramatikal komparatif (perbandingan) yang mengacu ke kadar kualitas atau intensitas yang sama atau mirip. Pada tuturan (3) kata 'kayak' (seperti) mengacu ke kadar kualitas atau intensitas sama, di mana Bunga tidak ingin disamakan seperti Hardi, di mana ketika memancing Hardi tidak mendapatkan ikan yang besar seperti yang didapatkan Bunga.

Pada tuturan (1) dan (4) terdapat penanda referensial yang berupa bentuk komparatif 'lebih' pada kalimat Yang ini lebih besar dan Tunggu aja ya aku pasti dapat lebih besar lagi. Kata 'lebih' pada kalimat tersebut mengacu ke kadar kualitas atau intensitas yang lebih atau yang kurang. Kata 'lebih' mengacu ke kadar kualitas atau intensitas yang lebih, di mana Bunga mendapatkan ikan yang lebih besar dibandingkan Hardi. Berdasarkan sifatnya maka penanda referensial ini bersifat eksoforis. 


\section{Data 1 (babak 3) \\ Indah: "Sebenarnya aku sangat sedih setelah Arya meninggalkan aku." \\ (Kembali ditatapnya Shinta dengan sorotan yang tajam), aku sangat menyayanginya, sebab ia sudah lebih dari teman seperti saudara ku sendiri. (1) \\ Shinta: "Sebaiknya kau telpon saja ibu Arya. Kau tanyakan bagaimana keadaannya sekarang." (2) \\ Indah: "Hal itu sudah aku coba kemarin tapi telpon $\mathrm{ku}$ tidak diangkat." (menundul lesu) (3) \\ (Dyta Aulia Andini, Kelas XI IPS 2)}

Pada tuturan (1) terdapat penanda referensial yang berupa bentuk komparatif sangat...pada kalimat Sebenarnya aku sangat sedih setelah Arya meninggalkan aku mengacu ke kadar kualitas atau intensitas yang paling tinggi di antarayang dibandingkan. Pada kalimat tersebut maksud yang dibandingkan jelas dan dipahami, hati Indah begitu sedih setelah ditinggal Arya. Berdasarkan sifatnya maka penanda referensial ini bersifat eksoforis.

Pada tuturan (1) terdapat kata seperti yang termasuk kohesi gramatikal komparatif (perbandingan) yang mengacu ke kadar kualitas atau intensitas yang sama atau mirip. Kata seperti pada kalimat aku sangat menyayanginya, sebab ia sudah lebih dari teman seperti saudara $k u$ sendiri mengacu ke kadar kualitas atau intensitas sama, di mana Arya yang diibaratkan seperti saudara sendiri pergi meninggalkannya.

\section{Data 1 \\ Dewi: Ada pa des, kok serius banget. Kamu ada masalah?? Ngomong aja sama kita-kita (1) \\ Desita: Sebenarnya aku dah pengen bilang dari tadi. Tapi aku bingung harus ngomongnya dari mana (2)}

(Ice Trisnawati, Kelas XI IPS 2)

Pada tuturan (1) terdapat penanda referensial yang berupa bentuk komparatif banget (sangat)....pada kalimat Ada pa Des, kok serius banget. Maksud yang dibandingkan jelas dan dipahami, Desita terlihat begitu serius seperti sedang memikirkan sesuatu. 'Banget' pada kalimat tersebut mengacu ke kadar kualitas atau intensitas yang paling tinggi di antara yang dibandingkan. Berdasarkan sifatnya maka penanda referensial ini bersifat eksoforis.

Pada tuturan (2) terdapat penanda referensial yang berupa bentuk komparatif 'banget' (sangat)....pada kalimat Mana? Oh iya, ganteng banget anak mana ya? Maujud yang dibandingkan jelas dan dipahami, Kania melihat seorang cowok yang sangat ganteng. 'Banget' pada kalimat tersebut mengacu ke kadar kualitas atau intensitas (wajah seorang cowok) yang paling tinggi di antara adjektiva yang dibandingkan. Berdasarkan sifatnya 
maka penanda referensial ini bersifat eksoforis.

\section{PENUTUP}

Berdasarkan hasil penelitian dan pembahasan yang telah diuraikan pada bab sebelumnya, dapat disimpulkan bahwa dalam naskah drama yang ditulis oleh siswa SMAN 2 Kandangan kelas XI IPA dan kelas XI IPS ada tiga peranti kohesi referensi yang digunakan, yaitu kohesi referensi pronomina (pengacuan), kohesi referensi demonstratif (penunjuk), dan kohesi referensi komparatif (perbandingan). Kohesi referensi pronomina persona adalah pronomina yang dipakai untuk mengacu pada orang. Pronomina persona terdiri atas persona orang pertama tunggal dan jamak, pronomina orang kedu tunggal dan jamak, dan pronomina orang ketiga tunggal dan jamak. Kohesi pronomina demonstratif adalah pronomina penunjuk umum, pronomina penunjuk tempat, dan pronomina penunjuk hal ikhwal. Kohesi referensi komparatif adalah kohesi referensi yang menyatakan perbandingan unsur yang satu dibandingkan dengan unsure yang lain. Kohesi referensi komparatif terdiri atas kohesi referensi komparatif yang menyatakan kurang, kohesi referensi komparatif yang menyatakan sama, dan kohesi referensi komparatif yang menyatakan lebih.

Penelitian ini merupakan gambaran kemampuan di dalam menggunakan peranti kohesi referensi dalam naskah drama siswa SMAN 2 Kandangan. Penelitian ini masih dalam tahap awal sehingga perlu penelitian yang lebih mendalam. Untuk itu peneliti mengharapkan adanya penelitian lebih lanjut. Hasil penelitian ini hendaknya dapat menjadi masukkan khususnya bagi guru yang mengajar di sekolah tersebut.

\section{DAFTAR PUSTAKA}

Abdul, Rani dkk. 2006. Analisis Wacana Sebuah Kajian Bahasa dalam Pemakaian. Malang: Bayu Media Publishing.

Halliday, M., \& Hasan, R. 1976. Cohesion in English. London: Longman.

Indiyastini, Titik. 2006. "Referensi sebagai Alat Kohesi Paragraf Deskriptif dalam Bahasa Jawa". Widyaparwa Jurnal Ilmiah Kebahasaan dan Kesastraan,volume 34, No. 1, Juni 2006. Jakrta: Pusat Bahasa Departemen Pendidikan Nasional.

Moeliono. 2003. Tata Bahasa Baku Bahasa Indonesia. Jakarta: Balai Pustaka.

Moleong, LI. 2012. Metodologi Penelitian Kualitatif. Bandung: PT Remaja Rosdakarya.

Mulyana. 2005. Kajian Wacana Teori, Metode, dan Aplikasi Prinsip-prinsip Analisis Wacana. Yogyakarta: Tiara Wacana. 
Analisis Penggunaan Kohesi Referensi pada Nasakah Dranma Siswa SMAN 2 Kandangan (Indrawati)

Mulyati, Y. 2002. Pendidikan Bahasa dan Sastra Indonesia di Kelas Tinggi. Jakarta: Universitas Terbuka.

Reinking, J.A., Hart, A.W. \& Osten, R.V.D. 1988. Strategis for Successful Writing. New Jersey: Prentice-Hall, Inc.

Sudaryanto. 1993. Metode dan Aneka Teknik Analisis Bahasa. Yogyakarta: Duta Wacana University Press.

Suladi, dkk. 2000. Kohesi dalam Media Massa Cetak Bahasa Indonesia: Studi Kasus tentang Berita Utama dan Tajuk. Jakarta: Pusat Bahasa.

Syafi'ie, I. 1988. Retorika dalam Menulis. Jakarta: Depdikbud Dirjen Dikti Proyek Pengembangan Lembaga Pendidikan Tenaga Kependidikan.

Tarigan, Henry Guntur. 2000. Menulis Sebagai Suatu Keterampilan Berbahasa. Bandung: Angkasa. 